\title{
Ischemia-modified albumin use as a prognostic factor in coronary bypass surgery
}

\author{
Muhip Kanko ${ }^{1 *}$, Sadan Yavuz ${ }^{1}$, Can Duman ${ }^{2}$, Tulay Hosten ${ }^{3}$, Emin Oner ${ }^{1}$ and Turan Berki ${ }^{1}$
}

\begin{abstract}
Background: Various types of markers have been used so far in order to reveal myocardial perfusion defect. However, these markers usually appear in the necrosis phase or in the late stage. Having been the focus of various investigations recently, ischemia-modified albumin (IMA) is helpful in establishing diagnosis in the early stages of ischemia, before necrosis develops.

Methods and Results: 30 patients that underwent only coronary bypass surgery due to ischemic heart disease within a specific period of time have been included in the study. IMA levels were studied in the preoperative, intraoperative, and postoperative periods. The albumin cobalt binding assay was used for IMA determination. Hemodynamic parameters (atrial fibrillation, the need for inotropic support, ventricular arrhythmia) of the patients in the postoperative stage were evaluated. Intraoperative measurement values (mean \pm SD) of IMA (0.67677 \pm $0.09985)$ were statistically significantly higher than those in the preoperative $(0.81516 \pm 0.08894)$ and postoperative $(0.70477 \pm 0.07523)$ measurements. Considering atrial fibrillation and need for inotropics, a parallelism was detected with the levels of IMA.
\end{abstract}

Conclusions: IMA is an early-rising marker of cardiac ischemia and enables providing a direction for the treatment at early phases.

Keywords: Coronary artery bypass surgery, ischemia-modified albumine, myocardial ischaemia

\section{Background}

Recent studies show that the structure of serum albumin changes when ischemia develops in the body. From this point of view, studies focusing on a new marker for myocardial ischemia have been carried out. Ischemia Modified Albumin is a new marker used to detect myocardial ischemia and it shows an early change $[1,2]$. Elevations in IMA levels have been detected following percutaneous coronary interventions [3,4]. It is also used for differential diagnosis in patients admitting to emergency departments with angina pectoris [5]. It has recently been reported that IMA also increases in case of pulmonary infarction, critical limb ischemia, cerebrovascular disease conditions [6-10].

Ischemia-modified albumin (IMA), a Food and Drug Administration-approved serum biomarker of cardiac ischemia and a risk stratification tool for suspected

\footnotetext{
* Correspondence: muhipkanko@yahoo.com

'Kocaeli University Medical Faculty Department of Cardiovascular Surgery;

41380; Kocaeli, Turkey

Full list of author information is available at the end of the article
}

acute coronary syndrome, is produced during an ischemic condition or attack and is present in the blood in early and easily detectable levels [5,11]. The increase in markers that predict myocyte necrosis during or after CABG surgery usually parallels with a poor prognosis of the patient. Numerous markers have been used to reveal myocardial necrosis until today $[12,13]$. These markers have been used as diagnostic criteria for myocardial necrosis that develops after CABG operations [14]. IMA is a marker formed after damage in the $\mathrm{N}$ terminal region of the albumin in ischemic conditions. Endothelial or extracellular hypoxia, acidosis, and free oxygen radicals have been shown to cause IMA increase [15]. In this study, we have intended to determine the association between IMA levels and hemodynamic parameters of the patients.

\section{Materials and methods}

The study was planned upon obtaining approval from the ethics board of our hospital. 30 patients, on which merely CABG was to be performed within a certain

\section{Biomed Central}


time frame, were included in the study. Patients who required concurrent valve or another cardiac intervention were not included in the study. Patients with serious liver, kidney, peripheral vascular, or cerebral pathologies were also excluded from the study.

\section{Surgical procedure}

Anesthetic management was uniform in all patients. Midazolam was used for premedication, and a combination of fentanyl, midazolam and pancuronium was used for the induction. After intubation, mechanical ventilation with oxygen and nitrogen was initiated. Anesthesia was maintained with midazolam, vecuronium bromide and inhaled sevoflurane. Patients were all operated on by the same surgical team. CABG was performed with moderate hypothermia. After the aorta was crossclamped and $1000 \mathrm{~mL}$ of high-potassium cold-blood cardioplegic solution $\left(24^{\circ}\right.$ to $\left.26^{\circ} \mathrm{C}\right)(10-15 \mathrm{~mL} / \mathrm{kg})$ was perfused one time in an antegrade, myocardial revascularization was performed during cardioplegic arrest at $28^{\circ} \mathrm{C}$ to $30^{\circ} \mathrm{C}$. The cardioplegic solution was composed of whole blood with a hemoglobin level of $8 \mathrm{~g} / \mathrm{dL}$ and $25 \mathrm{mEq} / \mathrm{L} \mathrm{KCl}$. Following antegrade cardioplegia, cardioplegia solution containing $10 \mathrm{mEq} / \mathrm{L} \mathrm{KCl}$ was constantly administered via retrograde path through the coronary sinus. Distal anastomoses were made. Proximal anastomoses were performed under side clamping. Following the completion of the surgery, the patients were taken to intensive care. Standard postoperative care was given to all the patients. Extubation was performed at the earliest stage possible following the provision of hemodynamic stability. The first choice when inotropic agent requirement emerged was dopamine. At times when atrial fibrillation occurred, amiodarone was the first choice for treatment in case laboratory and blood gas values were normal.

\section{Biochemical assays}

Blood samples were drawn from the coronary sinus right before cross-clamping and 30 minutes after crossclamping. Six hours after the operation, other blood samples were taken from a central venous catheter, which was forwarded into the right atrium and the IMA levels were studied. The blood samples were placed in flat tubes and kept waiting for 30 minutes, then sera were separated by centrifuging at $3000 \mathrm{rpm}$ for $10 \mathrm{~min}$ utes. Then the obtained serum samples were subjected to measurement immediately. Albumin Cobalt binding test was analyzed according to the method defined by Bar-Or et al. [16]. In this method $200 \mathrm{~mL}$ serum was added to the water solution of $50 \mathrm{~mL} \% 0,1(\mathrm{w} / \mathrm{v})$ cobalt chloridine (sigma; $\mathrm{CoCl}_{2} \cdot 6 \mathrm{H}_{2} \mathrm{O}$ ). It was mixed gently and waited for 10 minutes for sufficient cobalt-albumin binding. Then $50 \mathrm{~mL}$ dithiothreitol (DTT) (Sigma 1.5 $\mathrm{mg} / \mathrm{mL}_{2} \mathrm{O}$ ) was added as a colorizing agent. After waiting for two minutes $1.0 \mathrm{~mL} 0.9 \% \mathrm{NaCl}$ was added to stop the cobalt binding process of albumin. Afterwards, the absorbance was measured through spectrophotometer at $470 \mathrm{~nm}$ (Shimadzu, model UV160U). Sample blank without DTT were used as blind. The results were reported as absorbance units (ABSU).

\section{Statistical Analysis}

The analyses were performed using SPSS for Windows, version 13.0. Normal distribution test was applied. Due to its preoperative variable that does not confirm to normal distribution, non-parametric tests were performed in comparisons containing the preoperative variable. Based on the normal distribution analysis of data, the Friedman test, Wilcoxon Signed Rank test and Paired sample t test were used in the comparisons of the dependent groups, while independent group comparisons were conducted using the Mann-Whitney U test. The level of statistical significance was taken as p < 0.05 and the Bonferroni correction was used where needed.

\section{Results}

22 of the patients were males while 8 were females. The mean age of the patients was 58,6 (39 to 79). The demographics characteristics of the patients are given in the Table 1. In the echocardiograms of the cases, the ejection fractions were $35 \%$ and below in 12 cases (40\%); between $36 \%$ and $50 \%$ in 7 cases $(23 \%)$ and above $51 \%$ in 11 cases (37\%). Single-vessel bypass surgery in one case, 2-vessel bypass surgery in another case, 3-vessel bypass surgery in 11 cases, 4-vessel bypass surgery in 14

Table 1 Demographics characteristics of the cases

\begin{tabular}{ccc}
\hline & & $\%$ \\
\hline Age (years) & 58,6 & \\
\hline Male, $\boldsymbol{n}$ (\%) & 22 & $-73 \%$ \\
\hline Diabetes Mellitus, $\boldsymbol{n}$ & 11 & $-36 \%$ \\
\hline Hypertension, $\boldsymbol{n}$ & 15 & $-50 \%$ \\
\hline Smoking, $\boldsymbol{n}$ & 17 & $-56 \%$ \\
\hline Ejection Fraction, $\boldsymbol{n}$ & 12 cases $35>$ & $-40 \%$ \\
& 7 cases $36-50$ & $-23 \%$ \\
\hline Cardiopulmoner bypass time(Mean) & 11 cases $51<$ & $-37 \%$ \\
\hline Cross clamp time(Mean) & 81 min. & \\
\hline Number of bypass vessel, $\boldsymbol{n}$ & 37 min. & \\
\hline & CABG $\times 1 . . .1$ & $-3 \%$ \\
& CABG $\times 2 . .1$ & $-3 \%$ \\
& CABG $\times 3 . . .11$ & $-33 \%$ \\
& CABG $\times 4 . .14$ & $-42 \%$ \\
& CABG $\times 5 . . .3$ & $-9 \%$ \\
\hline LIMA graft use, $\boldsymbol{n}$ & 27 & $-90 \%$ \\
\hline
\end{tabular}


cases, and 5-vessel bypass surgery in 3 cases were performed. LIMA was used as a graft for LAD bypass in a total of 27 cases. For other vessel bypasses, Vena saphena magna (the great saphenous vein) was used. One (3\%) of the cases died. The mean cardiopulmonary bypass duration was 81 minutes and the mean crossclamping duration was 37 minutes. In 23 (76\%) patients, a need for a cardiotonic occurred while two (7\%) cases required intra-aortic balloon. Cases in whom intra aortic balloon was needed were urgent patients who were taken to bypass surgery in a hemodynamically unstable condition. Arrhythmias not requiring treatment developed in $11(36 \%)$ of the cases in the postoperative period. Paroxysmal AF attacks developed in 16 (53\%) cases during the postoperative period and 6 of these cases needed treatment for more than 72 hours. All the cases were discharged from the hospital with sinusoidal rhythm. Preoperative, peroperative, and postoperative changes in IMA of the patients were compared, and it was observed that these changes were significantly different from each other (Friedman test, $\mathrm{p}<0.05$ ). Postoperative IMA measurement values were higher than those of preoperative IMA. There was a statistically significant difference between the preoperative and postoperative measurements $(\mathrm{p}=0.011)$ (Wilcoxon signed rank test). In terms of preoperative IMA measurements and intraoperative measurements, the IMA levels at the intraoperative stage were higher. The difference between these values were statistically significant $(\mathrm{p}<0.001)$ (Wilcoxon signed rank test). When comparing the intraoperative and postoperative measurements of IMA, intraoperative phase levels were higher again and the difference between them was statistically significant $(\mathrm{p}=$ 0.001) (Paired sample t test) (Figure 1). Arrhythmias not requiring treatment developed in 11 (36\%) of the cases in the postoperative period. Paroxysmal AF attacks developed in 16 (53\%) cases during the postoperative

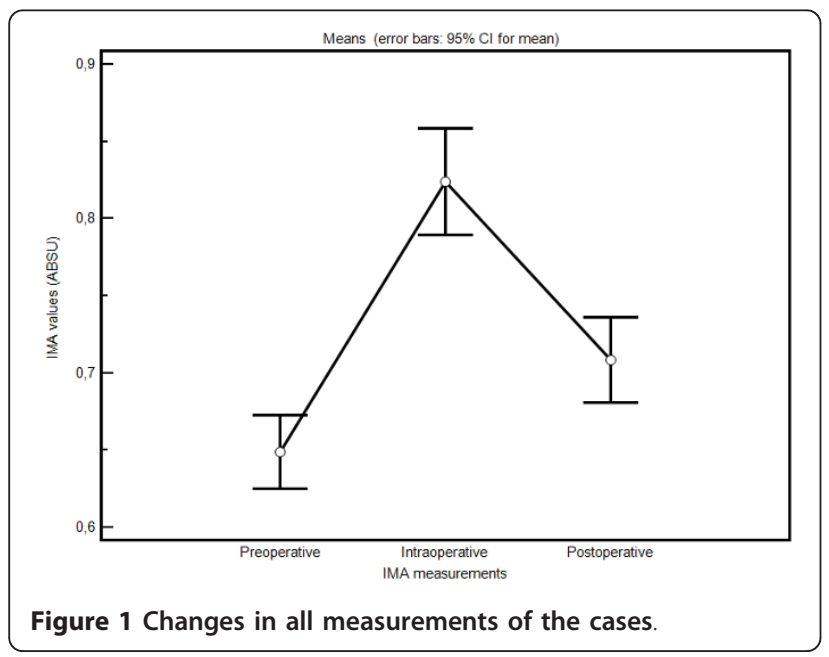

period and 6 of these cases needed treatment for more than 72 hours. All the cases were discharged from the hospital with sinusoidal rhythm. $23(76 \%)$ of the cases required an inotropic (7-15 microgram $/ \mathrm{kg} / \mathrm{min}$ dopamine). The need for an inotropic disappeared in five of the cases within 6 hours. However, 15 of these cases needed an inotropic support of $10 \mathrm{mcg} / \mathrm{kg} / \mathrm{min}$ for 24 hours and more. In two (7\%) cases taken to surgery in emergency settings and with intra-aortic balloon support and in one case with a low ejection fraction, there was a need for combined inotropics (dopamine, dobutamine, adrenaline, and noradrenaline). This support was required for at least 72 hours. Mortality occurred in one (3\%) case and this was a patient who was taken into an emergency bypass operation. When the relationship between the changes in hemodynamic parameters and IMA changes in the patients was examined, no statistical significance was identified (Mann-Whitney U, p > 0.05).

\section{Discussion}

Myocardial ischemia in various degrees may develop during the intraoperative phase due to such reasons as manipulation of the heart, inadequate myocardial protection, and incomplete revascularization. In order to reveal myocardial perfusion defect, such markers as AST, myoglobin, myocardial creatine kinase isoenzymes, and troponin have been used until today $[12,17,18]$. Recent studies show that the structure of serum albumin changes when ischemia develops in the body. Normal human albumin has the $\mathrm{N}$ terminal region, which detoxifies free oxygen radicals. The $\mathrm{N}$ region is also the area to which such transition metals as cobalt, copper and nickel are bound. In the ischemia condition, the $\mathrm{N}$ region is damaged by oxygen radicals. Albumin's capacity to bind metals such as nickel, cobalt and copper is diminished $[7,14,19]$. The resultant albumin as such is IMA. The type of the radical that affects the $\mathrm{N}$ terminal region most is the hydroxyl radical. Free radical binding capacity of IMA is very low. Elevation of IMA is directly associated with free radicals that form during ischemia [20]. IMA is also one of the markers of oxidative stress $[21,22]$. Reperfusion after ischemic conditions includes more free radical and iron and copper exposure, which may cause even more alterations to albumin than ischemia itself $[23,24]$. In studies conducted in earlier years, it was shown that IMA levels elevate in cardiac ischemia, cerebrovascular occlusion, pulmonary ischemia, gastrointestinal ischemia, and muscle ischemia [3,7,8,19,25-27].

A study conducted to scrutinize IMA specifies that IMA elevation may occur due to coronary vasospasm [5]. In other words, while the other markers for cardiac ischemia necessitate necrosis formation, IMA is elevated even in the early stages of ischemia. The most important 
characteristic that differentiates IMA from other cardiac ischemia markers is that it increases in the early phase particularly. It elevates in just minutes, peaks within 2 to 4 hours and returns to normal in 6 to 12 hours $[3,28]$. Non-existence of myocardial ischemia is considered to be confirmed in $90-95 \%$ of the cases if IMA levels are normal in the presence of a normal ECG and normal troponin levels [5]. Rapid elevation of IMA in minutes could render it usable in patient follow up and for taking necessary precautions rather earlier.

In this study, we examined the effects of coronary bypass operations on IMA levels and linkage of these levels with hemodynamic parameters. It was determined in a previous study that IMA levels increased shortly after the operation and decreased later on. However, it was stated that the amount of this decrease was still higher than basal levels [29]. In our study, we found that IMA levels elevated rapidly in the first 30 minutes following cross-clamping and decreased during the postoperative 6-hour-phase. However, the amount of this decrease did not reach to the level of the preoperative values. We believe that this can be attributed to a temporary effect created by reperfusion. In our study, IMA levels in the samples taken during the intraoperative stage were statistically higher than those obtained in the preoperative and postoperative periods.

Atrial fibrillation is observed in 7 to $40 \%$ of the cases after coronary bypass surgery [30,31]. Paroxysmal AF attacks emerged in $53 \%$ of our cases. The rate of atrial fibrillation that necessitated treatment for more than 72 hours was $20 \%$.

One of the major factors that determines the need for inotropics during the postoperative period is the duration of cross-clamping. If the duration of cross-clamping is longer than 90 minutes, the need for inotropics increases [31]. In $23(76 \%)$ of our cases, a need for an inotropic (7-15 microgram $/ \mathrm{kg} / \mathrm{min}$ dopamine) developed. Inotropic support of $10 \mathrm{mcg} / \mathrm{kg} / \mathrm{min}$ for 24 hours and more became necessary in $15(50 \%)$ of the cases that required an inotropic. Arrhythmia that did not require any need for treatment developed in 11 (36\%) of the cases in the postoperative period. When the cases with prolonged inotropic need as well as the cases with atrial fibrillation who needed treatment for more than 72 hours (6 cases) were examined, it was understood that the postoperative IMA levels in these patients remained higher than the rest of the cases. Although intraoperative IMA levels were statistically significantly higher in all cases, it was found that especially in some cases, arrhythmias lasted longer and more need for inotropics was present. This finding may imply a suspected presence of a subgroup specific to myocardium. Ventricular arrhythmia, atrial fibrillation, and inotropic requirement were found to be more in patients whose IMA values were measured higher. While this excess was not statistically significant, it was proportionally higher (in terms of the $\%$ value). It might be possible to attain statistical significance by increasing the number of the patients. Comparing with the preoperative stage, IMA levels were elevated more in samples taken 6 hours after the operation. The reason for this could be a temporary ischemic condition caused by reperfusion. We believe that these levels would come closer to basal values in the samples to be taken in the upcoming hours. The most important factor that restricts the use of IMA is that it is not a specific marker for myocardium. That being said, IMA may increase in some conditions (septic shock, renal failure, neoplasia, etc.) [32].

\section{Conclusion}

Many further studies are required in order to determine the role of IMA in ischemic conditions that occur in various organs. Sensitivity of cells to ischemia varies from one organ to another. It is important to know the optimal IMA levels to diagnose ischemia particularly in organs such as the heart and brain. Increasing the number of the cases and lengthening measurement periods in these types of studies might help establish this optimal level. IMA is one of the markers that show myocardial ischemia earliest. There is a parallel association between IMA levels and hemodynamic parameters of the patients. The most important factor that restricts IMA is that IMA may elevate in other pathologies as well, which brings about a requirement for subgroup studies. Since IMA is an early marker, measurement of IMA levels may contribute to patient follow up and initiation of treatment at early stages.

\section{List of abbreviations}

IMA: ischemia modified albumin; CABG: coronary artery bypass grafting; LIMA: Left internal mammarian artery; LAD: Left anterior descending artery; AF: Atrial fibrillation; DTT: dithiothreitol; ABSU: Absorbance Units; AST: aspartate aminotransferase.

\section{Author details}

'Kocaeli University Medical Faculty Department of Cardiovascular Surgery; 41380; Kocaeli, Turkey. ${ }^{2}$ Canakkale Onsekiz Mart University Medical Faculty Department of Biochemistry; 17100, Canakkale, Turkey. ${ }^{3}$ Kocaeli University Medical Faculty Department of Anaesthesiology; 41380, Kocaeli, Turkey.

\section{Authors' contributions}

MK conceived of the study, participated in its design and coordination. and drafted the manuscript. SY participated in the design of the study and performed the statistical analysis. All authors have read and approved the final manuscript

\section{Competing interests}

The authors declare that they have no competing interests.

Received: 2 September 2011 Accepted: 5 January 2012 Published: 5 January 2012 


\section{References}

1. Christenson RH, Duh SH, Sanhai WR, Wu AH, Holtman V, Painter P, Branham E, Apple FS, Murakami M, Morris DL: Characteristics of an albumin cobalt binding test for assessment of acute coronary syndrome patients: a multicenter study. Clin Chem 2001, 47:464-470.

2. Bhagavan NV, Lai EM, Rios PA, Yang J, Ortega-Lopez AM, Shinoda H, Honda SA, Rios CN, Sugiyama CE, Ha CE: Evaluation of human serum albumin cobalt binding assay for the assessment of myocardial ischaemia and myocardial infarction. Clin Chem 2003, 49:581-585.

3. Bar-Or D, Winkler JV, Vanbenthuysen K, Harris L, Lau E, Hetzel FW: Reduced albumin -cobalt binding with transient myocardial ischemia after elective percutaneous transluminal coronary angioplasty: a preliminary comparison to creatine kinase-MB, myoglobin, and troponin. I Am Heart J 2001, 141:985-991.

4. Quiles J, Roy D, Gaze D, Garrido IP, Avanzas P, Sinha M, Kaski JC: Relation of ischemia-modified albumin (IMA) levels following elective angioplasty forstable angina pectoris to duration of balloon-induced myocardial ischemia. Am J Cardiol 2003, 92:322-324.

5. Sinha M, Roy D, Gaze D, Collinson P, Kaski JC: Role of 'ischemia modified albumin', a new biochemical marker of myocardial ischaemia, in the early diagnosis of acute coronary syndromes. Emerg Med J 2004, 21:29-34

6. Roy D, Quiles J, Sharma R, Sinha M, Avanzas P, Gaze D, Collinson P, Carlos Kaski J: Ischemia-modified albumin concentrations in patients with peripheral vascular disease and exercise-induced skeletal muscle ischemia. Clin Chem 2004, 50(9):1656-60.

7. Gunduz A, Turedi S, Mentese A, Altunayoglu V, Turan I, Karahan SC, Topbas M, Aydin M, Eraydin I, Akcan B: Ischemia-modified albumin levels in cerebrovascular accidents. Am J Emerg Med 2008, 26(8):874-8.

8. Colak T, Duman C, Bamac B, Aydin A, Ozbek A, Yildiz K, Bicer U: Ischaemia modified albumin levels folloving mild closed head trauma in the rat. Turkive Klinikleri J Med Sci 2010, 30(4):1171-6.

9. Turedi S, Gunduz A, Mentese A, Karahan SC, Yilmaz SE, Eroglu O, Ucar U, Karaca Y, Turkmen S, Russell RM: Value of ischemia-modified albumin in the diagnosis of pulmonary embolism. Am J Emerg Med 2007, 25(7):770-3.

10. Gunduz A, Mentese A, Turedi S, Karahan SC, Mentese U, Eroglu O, Turkmen S, Turan I, Ucar U, Russell R, Balaban F: Serum ischemia-modified albumin increases in critical lower limb ischemia. Emerg Med J 2008, 25:351-353.

11. Peacock F, Morris DL, Anwaruddin S, Christenson RH, Collinson PO, Goodacre SW, Januzzi JL, Jesse RL, Kaski JC, Kontos MC, Lefevre G, Mutrie D, Sinha MK, Uettwiller-Geiger D, Pollack CV: Meta-analysis of ischemiamodified albumin to rule out acute coronary syndromes in the emergency department. Am Heart J 2006, 152:253-262.

12. Costa MA, Carere RG, Lichtenstein SV, Foley DP, de Valk V, Lindenboom W Roose PC, van Geldorp TR, Macaya C, Castanon JL, Fernandez-Avilèz F, Gonzáles JH, Heyer G, Unger F, Serruys PW: Incidence, predictors, and significance of abnormal cardiac enzyme rise in patients treated with bypass surgery in the arterial revascularization study (ARTS). Circulation 2001, 104:2689-2693.

13. Klatte K, Chaitman BR, Theroux P, Gavard JA, Stocke K, Boyce S, Bartels C, Keller $B$, Jessel $A$ : Increased mortality after coronary artery bypass graft surgery is associated with increased levels of postoperative creatine kinase-myocardial band release. J Am Coll Cardiol 2001, 38:1070-1077.

14. Thygesen K, Alpert JS, White HD: On behalf of the Joint ESC/ACCF/AHA/ WHF Task Force for the Redefinition of Myocardial Infarction. Eur Heart J 2007, 28:2525-2538.

15. Erturk E, Cekic B, Geze S, Kosucu M, Coskun I, Eroglu A, Ulusoy H, Mentese A, Karahan C, Kerimoglu S: Comparison of the effect of propofol and $\mathrm{N}$-acetyl cysteine in preventing ischaemia-reperfusion injury. Eur J Anaesthesiol 2009, 26(4):279-84

16. Bar-Or D, Lau E, Winkler JV: A novel assay for cobalt-albumin binding and its potential as a marker for myocardial ischemia: a preliminary report. $J$ Emerg Med 2000, 19:311-315.

17. Brener SJ, Lytle BW, Schneider JP, Ellis SG, Topol EJ: Association between CK-MB elevation after percutaneous or surgical revascularization and three-year mortality. J Am Coll Cardiol 2002, 40:1961-1967.

18. Januzzi JL, Lewandrowski K, MacGillivray TE, Newell JB, Kathiresan S, Servoss SJ, Lee-Lewandrowski E: A comparison of cardiac troponin T and creatine kinase-MB for patient evaluation after cardiac surgery. J Am Coll Cardiol 2002, 39:1518-1523.
19. Talwalkar SS, Bon Homme M, Miller JJ, Elin RJ: Ischemia modified albumin, a marker of acute ischemic events: a pilot study. Ann Clin Lab Sci 2008, 38(2):132-7.

20. Roy D, Quiles J, Gaze DC, Collinson P, Kaski JC, Baxter GF: Role of reactive oxygen species on the formation of the novel diagnostic marker ischaemia modified albumin. Heart 2006, 92:113-114.

21. Collinson PO, Gaze DC: Ischaemia-modified albumin: clinical utility and pitfalls in measurement. J Clin Pathol 2008, 61(9):1025-8.

22. Senes M, Kazan N, Coșkun O, Zengi O, Inan L, Yücel D: Oxidative and nitrosative stress in acute ischaemic stroke. Ann Clin Biochem 2007, 44(Pt 1):43-7.

23. Fransen EJ, Maessen JG, Hermens WT, Glatz JFC, Burman WA: Perioperative tissue injury and the release of inflammatory mediators in coronary artery bypass graft patients. Cardiovascular Research 2000, 45:853-859.

24. Dusec J, St'asek J, Tichy M, Bis J, Gregor J, Vojacek J, Masin V, Polansky P, Brtko M, Cernohorsky D: Prognostic significance of ischemia modified albumin after percutaneous coronary intervention. Clinica Chimica Acta 2006, 367:77-80

25. Falkensammer J, Stojakovic T, Huber K, Hammerer-Lercher A, Gruber I, Scharnagl H, Fraedrich G, Santner W, Schocke M, Greiner A: Serum levels of ischemia-modified albumin in healthy volunteers after exercise-induced calf-muscle ischemia. Clin Chem Lab Med 2007, 45(4):535-40.

26. Apple FS, Quist HE, Otto AP, Mathews WE, Murakami MM: Release characteristics of cardiac biomarkers and ischemia-modified albumin as measured by the albumin cobalt-binding test after a marathon race. Clin Chem 2002, 48(7):1097-100.

27. Abboud H, Labreuche J, Meseguer E, Lavallee PC, Simon O, Olivot JM, Mazighi M, Dehoux M, Benessiano J, Steg PG, Amarenco P: Ischemiamodified albumin in acute stroke. Cerebrovasc Dis 2007, 23(2-3):216-20.

28. Sinha MK, Gaze DC, Tippins JR, Collinson PO, Kaski JC: Ischemia modified albumin is a sensitive marker of myocardial ischemia after percutaneous coronary intervention. Circulation 2003, 107(19):2403-5.

29. Sbarouni E, Georgiadou P, Panagiotakos D, Alivizatos PA, Voudris V: Increased ischaemia modified albumin following coronary artery bypass grafting. Biomarkers 2009, 14(1):38-42

30. Siebert J, Anisimowicz L, Lango R, Rogowski J, Pawlaczyk R, Brzezinski M, Beta S, Narkiewicz M: Atrial fibrillation after coronary artery bypass grafting: does the type of procedure influence the early postoperative incidence? Eur J Cardiothorac Surg 2001, 19(4):455-9.

31. Bar-El Y, Adler Z, Kophit A, Kertzman V, Sawaed S, Ross A, Cohen O, Milo S: Myocardial protection in operations requiring more than $2 \mathrm{~h}$ of aortic cross-clamping. Eur J Cardiothorac Surg 1999, 15:271-5.

32. Kiyici A, Mehmetoglu I, Karaoglan H, Atalay H, Solak Y, Turk S: Ischemiamodified albumin levels in patients with end-stage renal disease patients on hemodialysis: does albumin analysis method affect albuminadjusted ischemia-modified albumin levels? J Clin Lab Anal 2010, 24(4):273-7.

\section{doi:10.1186/1749-8090-7-3}

Cite this article as: Kanko et al:: Ischemia-modified albumin use as a prognostic factor in coronary bypass surgery. Journal of Cardiothoracic Surgery 2012 7:3.

\section{Submit your next manuscript to BioMed Central and take full advantage of:}

- Convenient online submission

- Thorough peer review

- No space constraints or color figure charges

- Immediate publication on acceptance

- Inclusion in PubMed, CAS, Scopus and Google Scholar

- Research which is freely available for redistribution 